Valentyna Nykolaieva, Candidate of Pedagogical Sciences, Associate Professor of the Department of Sociology Management, Donetsk State University of Management (Mariupol, Ukraine)

\title{
REFORMING OF PUBLIC ADMINISTRATION OF SOCIAL SERVICE SYSTEM IN UKRAINE IN CONDITIONS OF SUSTAINABLE DEVELOPMENT
}

\begin{abstract}
Ukrainian society inherited a well-developed and expensive system of social services, which included various state institutions that belonged to different departments. Billions of hryvnias of budget funds were spent on these institutions, social services were not provided in full, and social services recipients were almost isolated from the family and society. Changing the priorities of state policy in solving these problematic issues requires not only legislative decision-making, but also practical implementation at all levels and, above all, at the local level, as well as reforming the system of public administration. The article describes the preconditions and peculiarities of the implementation of the reform of the social services system in Ukraine in order to successfully implement the goals of sustainable development. The article highlights the conceptual foundations of deinstitutionalization reforms in Ukraine. In the social policy of Ukraine, deinstitutionalization has become a top priority, primarily in the orphaned children social protection implementation, although it, to some extent, deals with other key categories involved in the process, namely, people with limited mental capabilities, the elderly, and offenders.
\end{abstract}

The main advantages and risks of implementing this reform are analyzed. The application of the gate-keeping mechanism is suggested. Successful deinstitutionalization is possible only with the close cooperation of the state, public, charitable and religious organizations. The actions of all branches must be coordinated and lead to a common result.

Keywords: public administration, social service system, deinstitutionalization, sustainable development

\section{Introduction}

The transition of Ukraine to sustainable socio-economic development, its integration into the European and world community requires the introduction of modern practices of interaction of the state and society, which would allow strengthening the mutual responsibility 
of all participants in public life, create conditions for the further stable development of society, based on the widest possible range of interests. A single policy of sustainable development is possible only with the comprehensive encouragement of regional and interregional social initiatives and projects.

First of all, it is necessary to develop a certain legal and regulatory framework that will allow for the structural adjustment of the network of institutions of the social sphere, which consists in the transfer of state-owned and municipal property to social facilities owned by other structures, with the provision of their financing at the expense corresponding budgets in the established order. At the same time, one of the most important directions of the policy of sustainable development of the social sphere should be the implementation of a set of measures for the creation and use of new technologies for the spread of social services, strengthening the material and technical base of social institutions and their technical equipment.

It should be noted that the foundation for the realization of the goals of sustainable development is the development at all levels of a peaceful and open community that is institutionally capable of effective action. A key role is played by effective public administration, which involves: ensuring personal safety of citizens, the rule of law and just justice; overcoming the organizational and financial foundations of criminal activity, corruption; increasing the effectiveness of public authorities and local self-government actions on the basis of openness and transparency of decision-making and public control over their implementation. Building peace, strengthening social cohesion and reducing the level of conflict-relatedness by all socially significant factors largely depend on the effectiveness of state authorities and local self-government. To accomplish tasks in this area, it is necessary to ensure the full participation of citizens in public administration and the life of local communities, to spread the practice of public-private partnership, to apply communication technologies, etc. (United Nations Ukraine, 2017).

There is the inconsistency between national, regional and local concepts, strategies and programs focused on the sustainable urban development (territories). In Ukraine there are dozens of national, regional and local programs and strategies that directly or indirectly relate to the sustainable development of territories. As a result of a permanent shortage of funds, or "freezing" the implementation of state target programs, their performance is very low. As a consequence, the goals defined in the state target programs are mostly not achieved. Therefore, there is an urgent need to identify specific key issues for achieving sustainable urban development (territories) with the development of specific measures and the definition 
of appropriate resource provision for their solution. All this requires revision (“audit"), as well as appropriate adjustments to existing targeted state programs (including coordination, synchronization of their goals) in order to achieve the goals of sustainable urban development (sustainable regional development).

Decentralization and management reform are aimed at building a transparent public administration system, creating a professional civil service, ensuring its effectiveness. The result of reforms should be the creation of an efficient, transparent, open and flexible public administration structure with the use of state-of-the-art information and communication technologies (e-government) capable of producing and implementing a coherent public policy aimed at sustainable social development and adequate responses to internal and external calls [Dynnyk 2015]. The goal of decentralization policy is to move away from the centralized model of governance in the state, to ensure the capacity of local self-government and to build an effective system of territorial organization of power in Ukraine, to fully implement the provisions of the European Charter of Local Self-Government, the principles of subsidiarity, universality and financial self-sufficiency of local self-government

Priority in public finance management should be to enhance transparency and efficiency in their distribution and spending. The process of public procurement should be as transparent as possible and take into account the general principles of competition. Characteristics of the main components of public administration reform are summarized in Table 1. 
Table 1. The Essence and Characteristics of the Components of Public Administration

\section{Reform}

\begin{tabular}{|c|c|}
\hline $\begin{array}{l}\text { Components } \\
\text { of reform }\end{array}$ & $\begin{array}{l}\text { Characteristics of the components } \\
\text { of public administration reform }\end{array}$ \\
\hline Temporary civil service & $\begin{array}{l}\text { Involvement of the civil service of qualitatively new specialists and } \\
\text { specialists in the implementation of changes in the spheres of business or civil } \\
\text { society. Such a mechanism involves: setting clear goals, objectives and key } \\
\text { performance indicators for the involved civil servants; adequate labor } \\
\text { remuneration through donor assistance, without additional use of budget } \\
\text { funds; transparency, publicity of raising funds and monitoring the } \\
\text { implementation of such a mechanism, limited in time not more than } 2 \text { years } \\
\text { from the moment of its realization. }\end{array}$ \\
\hline Civil service reform & $\begin{array}{l}\text { Introduction of innovations in the bill "On the Civil Service": the distinction } \\
\text { between political and administrative positions, exclusively competitive } \\
\text { selection for civil service (in particular senior management positions), } \\
\text { competent model of human resources management, harmonization of civil } \\
\text { service and service in local self-government bodies, optimization of functions, } \\
\text { reduction the number and establishment of a transparent model of } \\
\text { remuneration and responsibility for the decisions made. }\end{array}$ \\
\hline Government reform & $\begin{array}{l}\text { It should transform the Cabinet of Ministers into a body capable of being an } \\
\text { effective generator of changes in the state. For this purpose, it is necessary to } \\
\text { improve the Laws "On the Cabinet of Ministers of Ukraine" and "On Central } \\
\text { Executive Bodies", which will include: a) strategic activity of the } \\
\text { Government, based on basic policy analysis by monitoring the situation, } \\
\text { identifying problems, finding alternatives for solving these problems, etc. At } \\
\text { the same time, the leading role in the formulation of proposals for state policy } \\
\text { should be carried out by the ministries; b) raising collegiality and } \\
\text { transparency in the work of the Cabinet of Ministers through: the } \\
\text { legitimization of "government committees" as obligatory working bodies of } \\
\text { the Cabinet; introduction of a rule on obligatory early disclosure of } \\
\text { government decision-making projects; c) the reorganization of the ministries: } \\
\text { the delineation of the political functions of ministries and administrative } \\
\text { functions; the appointment of deputy ministers upon the submission of the } \\
\text { relevant ministers; introduction of posts of state secretaries of ministries; } \\
\text { defining the tasks of the ministries on the basis of the policy analysis } \\
\text { function; reorganization of departments of ministries as the main structural } \\
\text { subdivisions of the apparatus, oriented towards a holistic policy direction; } \\
\text { formation of typical secretariats of ministries as subdivisions of cross-border } \\
\text { provision (personnel, accounting); liquidation of territorial bodies of } \\
\text { ministries) the highly specialized agencies, inspections and services formed } \\
\text { exclusively on a professional basis in accordance with the law on civil } \\
\text { service; e) the development of a professional state apparatus through: } \\
\text { introduction of the posts of the Secretary of State and State Secretaries of the } \\
\text { ministries as higher, permanent, professional and politically neutral } \\
\text { specialists; the appointment of all civil servants solely on the basis of } \\
\text { competitive procedures in accordance with the law on civil service. }\end{array}$ \\
\hline
\end{tabular}


First of all, the new edition of the Law of Ukraine "On Civil Service" includes progressive domestic developments, successful European experience in the reform of the civil service institute (in particular Poland), recommendations and conceptual foundations of the professional civil service identified by SIGMA / OECP experts.

\section{The state of social care system in Ukraine.}

A significant component of the Sustainable Development Goals is the social security system, which includes social services. The system of social services in Ukraine needs to be improved and reformed. It is this question and this article is devoted.

The term "social service" also has a number of interpretations. The recommendations of the EU Committee on Social Protection of 10.08.2010 [Keller 2018:101] attempted to formulate common criteria and principles for social services. In this recommendation, it is stated that the official documents of the EU do not disclose the concept of "social services", but there are two criteria that allow him to define the following. Social services - is: established on the basis of legislative and voluntary social security schemes, organized in various ways services covering social risks related to health, aging, occupational accidents, unemployment, disability; other services that provide a person with an opportunity to maintain social cohesion and facilitate social inclusion in society. These services: are designed to help people who cannot independently overcome personal problems or crises (such as lack of livelihood, unemployment, family unhappiness); include actions that allow interested people to fully re-integrate into society (rehabilitation, language training for immigrants) and enter the labor market (vocational training and reintegration); they also complement and support the role of families in caring for the youngest and oldest members of society; include actions to unite people with long-term health problems or inability to live independently; services also include social housing for citizens who find themselves in a difficult life situation.

The Law of Ukraine "On Social Services" interprets the essence of social services as: "a system of social measures that involves the promotion, support and services that provide social services to individuals or groups of individuals in order to overcome or mitigate life difficulties, support their social status and full life activities. Social service is provided: at the place of residence of the person (at home); in residential institutions and institutions; in rehabilitation institutions and institutions; in institutions and day-care institutions; in institutions and establishments of temporary or permanent residence; in the territorial centers of provision of social services; in other institutions of social support (care)". 
The notion of social services in domestic and foreign practice is also an important issue, since everything else depends on the legal wording -the possibility or impossibility of a specific person to apply for social assistance and the amount of financial resources that the state should allocate for this type of social protection. The definition of the notion of social services is the most important lever of government control for the inclusion or exclusion of large cohorts of the population in the social services system. For example, in the practice of the work of social welfare agencies one can find many tools for assessing the need for social services. Initially, all countries applied general criteria affecting the deterioration of a person's physical condition. However, with the growing proportion of older people with various disabilities, these criteria began to be revised.

Back in the days of the Soviet Union rules, the system of social services in Ukraine was formed by large institutions (boarding schools, residential care home, psycho-neurological boarding schools, geriatric boarding houses, etc.) subordinated to different departments, based on the idea of collective education and collective defense. They did not employ professional social workers and did not apply ethical and professional standards of social work. Billions of hryvnias of budget funds were spent on those institutions maintenance, social services were not provided to the full extent, and the elderly, some groups of persons with disabilities were almost isolated from family and society. Changing the priorities in state policy in solving these problematic issues requires not only decisions at the legislative level but also practical implementation at all levels and, above all, at the local community one.

These institutions have been inherited by the modern social work system in Ukraine. Back in the 90's of the XX century the innovative non-stationary facilities development for the elderly, people with functional limitations, families. At the same time, the process was carried out at a rather slow pace, was unsystematic, without research and taking into account the requirements of the needy and community resources.

At the same time, there are 322 boarding houses for the elderly and disabled, 149 psycho-neurological boarding schools, 5 special boarding houses, 24 boarding houses, 9 specialized residential houses for veterans of war and labor, 289 rehabilitation institutions, 94 social protection institutions for homeless people and persons, released from prison [Ministry of Social Policy of Ukraine, 2018].

Analyzing the causes of people entering different establishments of abovementioned kinds, the most widespread among them can be identified, namely: 
1. Poverty as a significant proportion of families, families where one or more of the family members with a disability.

2. Lack of preventive social work at the community level.

3. Underdevelopment of inclusive education.

4. Low effectiveness of social services for families and individuals who have been in difficult living conditions.

5. The complexity of financial and organizational mechanisms of public administration.

The Research Laboratory of Laboure and Employment of the Population, as part of the Ministry of Social Policy Order, has conducted the sociological survey on the care quality in residential institutions. The questionnaire was conducted on 1,382 in wards of 138 residential institutions (survey method) in 2017. Assessing the overall level of satisfaction with the quality of service at the institution, the in wards $(52.7 \%)$ stated that they were completely satisfied, and $37.6 \%$ were rather satisfied. According to the author's opinion, positive results are due to the fear of closure, dependence on the boarding schools; the in wards assessed not only the quality of service but also the value of staying at the institution [Davydyuk 2018].

At the same time, most researchers insist on the negative consequences of the institutional care system in Ukraine:

- the employer receives less than the state allocates to the service recipient maintenance at the orphanage, which is a distortion of the social and labour policy of the state and contradicts the declared priorities of economic and human development;

- there is a ground for illegal actions, built on artificial maintenance and increasing the number of dependents, the actual deterioration of their conditions of stay;

- motivation for corruption and abuse is created;

- there is no motivation to improve the service quality provided by the institution;

- the staff qualification level of the residential institutions is low.

The basis of public policy in the provision of social work services ought to be the approach according to which people with different forms of social disadvantage must have the necessary individual support in the environment in which they live, work and where it is easy to see their real needs and to check the service quality provision. Social services provided at the community level should be as close as possible to the client's place of residence and aimed at ensuring that their users are not isolated, and feel community membership, integration into society [Kravchenko 2014]. 
In order to change the situation, the Strategy for Sustainable Development "Ukraine 2020" was approved, a document defining the directions and priorities for Ukraine's development until 2020. The strategy was developed on the initiative of the President of Ukraine Petro Poroshenko. "Strategy 2020" consists of four vectors: sustainable development of the country; security of the state, business and citizens; responsibility and social justice; pride for Ukraine in Europe and in the world. The motion vector "Responsibility and Social Justice" envisages the implementation of 14 reforms and programs: among them the social protection system reform. Therefore, at the same time, several very important reforms were launched at once. In particular, education and health, which are directly related to deinstitutionalization.

\section{The deinstitutionalization of the social service system}

According to the Ministry of Social Policy, in Ukraine there are about 2 million married couples aged 60 and over and more than 2 million elderly people living alone or separately from children. Among them, 754 thousand people need different types of household care, including those aged 75-80, over 300 thousand people. Studies show that $80 \%$ of people aged 75 and older cannot do without extra help. The domestic social care system is traditionally oriented mainly for the care of socially vulnerable people in inpatient facilities and in boarding schools.

The funds are directed towards the maintenance of state social institutions, and not for the needs of recipients of social services. The financing of institutions of a stationary type is carried out per person, rather than on a specific service of the consumer, that is, practically nobody seriously provides the assessment of what social services are needed in a particular region and in what amount; however, it is vital to make such an assessment, in addition it has to be done periodically in order to make the necessary adjustments when the situation changes. Such an approach leads to dispersed and inappropriate use of social expenditures, as well as abusive practice and corruption.

According to the latest data from the State Statistics Service of Ukraine, by the end of 2014, the number of boarding schools for adults in Ukraine is 241, with 41,269 people being served, and by the end of 2017 there were 238 boarding schools with 42,978 people.

In the world, there are various forms of placement for the elderly and disabled as an innovative form of social care (Table 2). 
Table 2. Classification of different forms for elderly and disabled people placement

\begin{tabular}{|l|l|l|}
\hline № & Forms of placement & Types of forms \\
\hline 1. & Family & $\begin{array}{l}\text { - admission to a family as a relative; } \\
\text { - custody of citizens, who are recognized as } \\
\text { incapacitated by the court; } \\
\text { - a hospice at home }\end{array}$ \\
\hline 2. & State-public (transitional) & $\begin{array}{l}\text { - the family home of the elderly; } \\
- \text { temporary foster families (foster families) for } \\
\text { the elderly; } \\
\text { - patronage families. }\end{array}$ \\
\hline 3. & State & $\begin{array}{l}\text { - state or municipal orphanages for the elderly; } \\
- \text { centers of temporary retention of elderly } \\
\text { people; } \\
\text { - hospice }\end{array}$ \\
\hline
\end{tabular}

The most effective forms of placement are family and transitional forms of the placement for the elderly, among which the following (in order of weakening the family component) can be allocated: the family of adoptive parents, guardian and patronage families, family homes of the elderly, temporary (fostering) host families.

Proceeding from the fact that in the program documents of European countries, which define the social policy development vector, home care, family-type services are priority for institutional care, the initiatives on the necessary increase in public expenditures for integrated care at the community level, coordination between medical and social services and the further reduction of in-patient care for the elderly are becoming actual.

There are a lot of disadvantages of institutional care for this category of people, namely: limited personal life, lack of independence and respect for the personal integrity can adversely affect emotional and physical well-being.

The transition issue from providing inpatient care to family forms of placement can be solved only within the framework of the legislation of Ukraine. At the same time, it is necessary to provide with legal methods the creation and application of all-Ukrainian standards of quality of life for older people in professional (foster) families, family-type homes throughout the country, as well as a unified mechanism for monitoring the rights and legitimate interests of citizens who will reside in families based on the principle equality of citizens' rights, regardless of the territory of the residence [Davydyuk 2016].

Public administration of the residential schools reformation process for the elderly is to develop mechanisms: regulatory (the Strategy development, amendments to the current legislation, elaboration of care standards and relevant supporting documents, property rights 
of consumers observance, etc.); organizational and personnel (qualifying personnel support, introduction of innovative services types, monitoring and control); informational (creation of a single information space and a single electronic database of potential providers of family services and recipients).

The Research Institute of Laboure and Employment of the Ministry of Social Policy of Ukraine and the National Academy of Sciences of Ukraine developed an algorithm for the social services for the elderly deinstitutionalization. At the same time, some researchers consider the process of deinstitutionalization is similar to the process of deinstitutionalization. The algorithm consists of two stages, namely, the preparatory and the implementation.

The first stage is preparatory which provides the following steps: 1 - assessment of the system and resources; 2 - development of normative documents on deinstitutionalization; 3 - organization of pilot surveys. The second stage is implementation that includes the following steps: 4 - creation of a single electronic database of subjects; 5 - specialists' training, support of family service providers and clients; 6 - organization of controlling and monitoring the needs of the elderly [Research Laboratory of Laboure and Employment 2016].

It ought to be noted that the process of deinstitutionalization requires significant financial costs from the state, therefore, the conditions of the socio-economic crisis in Ukraine and a significant reduction in incomes, the implementation of a "professional" family for the elderly and the disabled is the most optimal solution in order to improve the clients quality of life, and state payments to service providers will contribute to a partial improvement of their material condition.

\section{Conclusions}

When carrying out the reform it is necessary to take into account the experience of European countries. Sectoral reforms are subject to additional risks related to the consignment note on macroeconomic instability and to administrative-territorial reform and decentralization reform and the situation in the East of Ukraine. Among the main risks:

- optimization capture in order to achieve the best performance;

- undeveloped precise technological process;

- prevalence of normative approach;

- unclear division of responsibilities and coordination between all stakeholders;

- lack of financing and logistics;

- declaration and non-fulfillment of tasks;

- low skill level of personnel; 
- weak control and opacity of spending.

All of these risks can be minimized if management decisions are based on a comprehensive data analysis, localized innovations become traditional, there are flexibility and responsiveness in determining priorities and methods of impact and application of the gate-keeping mechanism, that is, if there operates competent authority responsible for conducting needs assessment acts, and there exist the decision making and client tracking in the social work and service delivery system. In order to balance national and regional powers, also with regard to resources for service reform and deinstitutionalization, the practice of planning at the regional / local level is well-established, with short, medium and long-term results defined.

It is a rather complicated reform, since boarding schools are run by three ministries. Successful deinstitutionalization is possible only with the close cooperation of the state, public, charitable and religious organizations. The actions of all branches must be coordinated and lead to a common result.

While carrying out any reform it is necessary to take into account the human factor, that is, changes in the attitude of employees to their duties and behavior and strengthening the officials' responsibilities. Intensive reform, accompanied by the creation of new competent authorities that does not affect the elimination of the previous one, can complicate the system and make it even less functional than before. The same can happen due to the unclear division of responsibilities and coordination between all stakeholders.

Depriving the social context of sustainable development makes this development meaningless. Therefore, the transition of Ukraine to sustainable development requires certain transformations of policy in the social sphere, the main priorities of which should be: preservation of human health; assistance in improving the demographic situation; provision of social guarantees to people in need of protection; achievement of standards of quality of life adopted in developed countries; reaching the benchmarks of the current level of rational consumption for all segments of the population; humanization of social relations by reforming governance, education, science, culture, health, as well as democratization of state institutions. Since social protection is also an investment in the "human infrastructure" of countries, the most important task of states at the present stage is to create an effective system of social services as a complex of services that help various categories of the population at risk to prevent or reduce poverty, insecurity and social exclusion. 


\section{References}

Boshnyak, V. (2010), Deinstitutionalization and reforms in the field of children's protection - two sides of one medal: a view from abroad // Children's rights, Vol.1, No9, pp. 7-9.

Dakal, A. (2016), Reforming the institutional care and children upbringing in the context of their rights protection // Public Administration: Theory and Practice, Vol.2, pp. 97-105 .

Davydyuk, O. (2016), Deinstitutionalization of social services for the elderly in Ukraine // Demography and Social Economics, Ukrainian scientific journal, Vol. 2, No. 27, pp.143-155. https://doi.org/10.15407/dse2016.02.143

Davydyuk, O. (2018), Subjective approach to assessing the quality of care in residential institutions // Demography and Social Economics, Ukrainian scientific journal, Vol. 2, No. 32, pp. 100-113. https://doi.org/10.15407/dse2018.01.100

Dynnyk, I. (2015), Development of the ukrainian state in the context of implementation of the Strategy for sustainable development "Ukraine - 2020"// Collection of scientific works. Efficacy public administration, Issue 43, pp. 264-271.

Keller Pavel (2017), The concept of social service in the vector of the living cycle of man in domestic and foreign practice // Conference proceedings "Human well-being, social cohesion and sustainable development: the quest for the responses to contemporary challenges. Moscow.

Kravchenko M. (2014), Mechanisms of decentralization of social services in Ukraine. Scientific Newsletter, Democratic Governance, Vol. 14. Available at: http://www.irbisnbuv.gov.ua/cgi-bin/irbis_nbuv/cgiirbis_64.exe?I21DBN=LINK\&P21DBN=UJRN\&Z21ID=

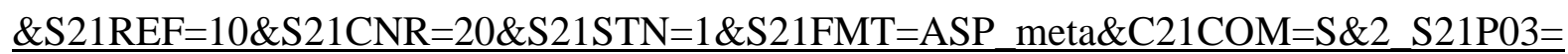
$\underline{F I L A=\& 2 \_S 21 S T R=D e V r \_2014 \_14 \_8}$

Law of Ukraine "On Social Services" (2003). Available at: https://zakon.rada.gov.ua/laws/show/966-15

Official site of the Ministry of Social Policy of Ukraine (2018). Available at: https://www.msp.gov.ua/

Research Institute of Labour and Employment (2016), Deinstitutionalization of Social Services: Some Aspects of Implementation in Ukraine. Available at: http://ipzn.org.ua/wpcontent/uploads/2016/06/Deinstytualizatsiya-sotsialnogo-obslugovuvannya.pdf

The Strategy of Sustainable Development "Ukraine 2020". Available at: http://www.president.gov.ua/documents/18688.html 
United Nations Ukraine, 2017. Available at: http://www.un.org.ua/ua/informatsiinyi$\underline{\text { tsentr/news/4202-uriad-ukrainy-zaprovadyv-novyi-kompleks-zavdan-ta-pokaznykiv- }}$ rozvytku-vidpovidno-do-zoboviazan-dosiahty-tsilei-staloho-rozvytku-do-2030-roku 